\title{
IPARI KLASZTEREK KOMMUNIKÁCIÓJA
}

A szerzők tanulmánya az ipari klasztereken belüli kommunikációval foglalkozik. Kutatási alapkérdésük, hogy van-e összefüggés a klaszter sikeressége és a klasztermenedzsment kommunikációs gyakorlata között. A kérdést a klaszter célja és stratégiája, a kommunikációmenedzsment és a sikeresség hármas viszonyában vetik alá vizsgálatnak. Az összefüggést annak alapján tárják fel, hogy milyen tárgyban, milyen gyakorisággal, milyen csatornákat, eszközöket és formákat igénybe véve, milyen eredményességgel és milyen sajátos klaszterjellemzők hatása alatt kommunikálnak egymással a gyakorlatban a klasztermenedzsment és a klasztertagok, valamint a klasztertagok egymás között. A sikeresség mércéje a klasztertagok sikerérzete. A kérdésükre a választ három dél-dunántúli ipari (egy kreatívipari, egy gépipari és egy kesztyűipari) klaszter 28 tagjával végzett interjús felmérésük eredményeiből nyerték. A három klaszter közül kettőnek a tagjai sikeresnek tartják saját klaszterüket, egyé kevésbé. Stratégiai céljaikban, a klaszteren belüli üzleti kapcsolataikban jelentős eltérések vannak, hasonló módon számos eltérés van kommunikációs gyakorlatukban is. A kirajzolódó tényeket esetismertetések formájában osztják meg az olvasókkal. A klasztereken belüli kommunikáció sajátságainak feltárásával mind a nemzetközi, mind a hazai kutatás adós. Ezen adósságból törleszt munkájuk, a gyakorlat számára is hasznos megállapításokat kínálva.?

Kulcsszavak: ipari klaszterek, klasztermenedzsment, kommunikációmenedzsment, klaszteren belüli kommunikáció, sikeresség

$\mathrm{T}$ anulmányunk Michael Porter és Lengyel Imre értelmezését követve, klaszteren egymással kölcsönösen, szorosan és valamilyen módon tartósan együttműködő gazdasági szereplők és velük kapcsolatban álló intézmények térbeli koncentrációját érti, amelyben a résztvevőket az adott témában vagy területen jellemzö hasonlóságaik és egymást kiegészítő tulajdonságaik kapcsolnak össze (Porter, 1990; Lengyel, 2001; Lengyel - Deák, 2002).

A klaszter célja, hogy a globalizált világban növelje, vagy legalább megőrizze egy térség verseny- és innovációs képességét. A gazdaság, a tudomány és a politika között kommunikációs platformot biztosítva a klaszterek abban segítenek, hogy a problémákat és lehetőségeket sikerüljön idejekorán felismeri, azonosítani és együtt megoldani (Hartmann, 2016). Gazdasági jelentőségük abban áll, hogy a tagok erősíteni tudják piaci pozíciójukat, hatékonyabbá tudják tenni a működést, racionalizálni tudják a tevékenységüket bizonyos tevékenységek koordinálásával, és javítani tudják imázsukat. E célok megvalósításának előfeltétele a megfelelő kommunikációmenedzsment.

A klaszterek sajátos hálózatos szerveződési formák, amelyek egyrészt rendelkeznek a szervezetek számos tulajdonságával, másrészt jellemzik őket azoktól megkülönböztető ismérvek is. Új szervezeti típusnak tekinthetök. Fő jellemzőik, hogy a klaszter tagjainak van közösen elfogadott célja, vannak közös érdekeik, a tagok belső érvényü szabályok alapján együttműködnek egymásssal és bizonyos szerepeket töltenek be. A klaszterek klasztervezetésből (board, klasztermenedzsment) és klasztertagokból állnak. A tagok lehetnek vállalkozások, vállalatok, intézmények, szervezetek, szövetségek. Tagstruktúrájuk többnyire azonos: jellemzően a gazdaságból, a tudományból

és a politikából kerülnek ki. Hosszabb időtávra létrejövő szerveződések, jellemző életciklusokon mennek keresztül. Ugyanakkor dinamikus szerveződések: folyamatosan bővülhetnek új tagokkal, a már meglévők egy-egy időszakra passzívvá válhatnak, sőt ki is léphetnek a klaszterből. Tevékenységük lehet azonos/hasonló vagy egymást kiegészítő, lehetnek egymás beszállítói és versenytársai is. Gyakori jellemző a klasztertagok közötti szakmaibaráti, közösségi kohézió. Az együttmüködés szolgálhat közvetlen üzleti célokat, vagy közvetetten járul hozzá a kitüzött cél eléréséhez. A klasztertagok a fizikai térben (egy településen, egy városrészen belül) sürü vagy ritka eloszlásúak (egymástól nagy távolságra helyezkednek el), és lehetnek országhatárokon átívelők is (nemzetközi klaszterek). Rendelkeznek az egységeket összekapcsoló kommunikációs csatornákkal és eszközökkel, folyamatos kapcsolatban állnak egymással. A tagok tagsági díjjal hozzájárulnak a klaszter kiadásainak fedezéséhez. Az információgyüjtést és a kommunikációt megkönnyíthetik olyan elektronikus platformok is, mint az eBEST, ami „lehetővé teszi a vállalkozások szervezett csoportokba, azaz ökoszisztémákba rendeződését, hozzá tud járulni a fogyasztói igények kielégítése érdekében létrejövő ellátási lánc, illetve egyedi folyamatok mentén fellépö információszerzési, kommunikációs vagy együttmüködési akadályok lebontásához" (Ternai - Borbásné, 2015, p. 57.).

Mindezek a jellemzők hatással vannak a klaszterek extern és intern kommunikációjára egyaránt. Jelen tanulmány a klasztereken belüli kommunikációt ragadja ki a kommunikáció komplex rendszeréböl. A szervezetek kommunikációját meghatározza a szervezet célja, tevékenysége, a szervezet mérete, életkora, a szervezetet al-

${ }^{1}$ Készült a szerzőknek az MTA Kommunikációmenedzsment Munkabizottsága „Az ipari klaszterek belső kommunikációja“ című, 2017. október 26-án, Budapesten rendezett konferenciáján tartott előadásai felhasználásával. 
kotó tagok ismérvei, és jelentős mértékben alakítja a szervezetet körülvevő gazdasági, jogi, technikai - műszaki, ökológiai és szociokulturális környezet. Hasonlóan hatnak e tényezők a klaszterek kommunikációjára is (Carbonara, 2005). A szervezeti méret kapcsán fontos megemlíteni egy magyar felmérést, amelynek konklúziója, hogy a multinacionális vállalatok Magyarországon müködő leányvállalatainak jelentős szerepük van a globális trendek és a nemzetközi standardok elterjesztésében a klasztereken belül, valamint a kis- és közepes vállalkozások (KKV-k) és a leányvállalatok közötti üzleti kapcsolatok menedzselésében is meghatározó tevékenységet végeznek (Kocsis, 2012). Hálózatos voltuk miatt azonban a klaszterek struktúrája nem azonos a hagyományos szervezetek kommunikációs struktúrájával (Zerfaß, 2004, p. 409.). Dinamikus szerveződésük is kihívást támaszt a klasztermenedzsment kommunikációs feladatai terén: új tagok integrálása alakítja a struktúrát, és egy taglétszámában változó klaszter újabb és újabb kommunikációs lépéseket igényel.

\section{A klaszterkommunikáció}

Bár a klasztereknek már az 1990-es, 2000-es években nőtt a jelentőségük, kommunikációjuk kutatása meglehetősen szerényen reprezentált a nemzetközi és a hazai szakirodalomban. „Míg a közelmúltban folytatott kutatások a klaszterekre pozitívan ható számos tényezőt vizsgáltak, a kommunikáció szerepe a klaszteren belül ... szinte egyáltalán nem kapott figyelmet" (Blassini et al., 2014, p. 120.). Mint a szerzők megállapítják, mindez annak ellenére van így, hogy mind a közgazdasági, mind a szociológiai klasztermodellek kitérnek a kommunikáció vitathatatlan fontosságára. A fontosság logikájával teljesen ellentétes, hogy a klasztermenedzsment kézikönyvek is (Cluster Navigators, 2001; Rosenfeld, 2002 etc.) a klaszterfejlesztés és a klasztermenedzsment mellékes tényezőjeként kezelik (Hartmann, 2016, p. 131.).

A klaszterekben alkalmazott kommunikációmenedzsment kutatásának elhanyagolása több okra vezethető vissza. Egyrészt a kommunikációmenedzsment-kutatás határterületi feladat, ezért egy kutatótól több tudományterület beható ismeretét igényli egyszerre, vagy olyan kutatóteamekben folytatható, amelyek a megfelelő diszciplínák müvelöiből tevődnek össze. „A kommunikációmenedzsment tudományos diszciplína, önálló, interdiszciplináris vállalkozás, amely nem korlátozható kommunikációtudományi módszerekre és ismeretekre, hanem a gazdaságtudományból, a szervezeti és szociálpszichológiából, a szociológiából, a politikatudományból, a nyelvészetből és más tudományágakból integrálja elméleti és módszerbeli perspektíváit" - írja Bentele és Will (2006, p. 154.). Másrészt mind a vállalati kommunikációmenedzsment, mind a klaszterek viszonylag új kutatási területet jelentenek. A fenti elméleti és módszerbeli perspektívákat a klaszterekre kiterjesztve müvelni, innovatív hozzáállást igényel a kutatóktól.

Német kutatók munkáinak sora ugyanakkor igazolja, hogy a professzionális kommunikációmenedzsment hatékonyan támogatja a vállalat céjainak, stratégiájának megvalósítását és mérhető módon pozitívan befolyásolja a vállalat eredményességét (Pfannenberg, 2005; Pfannenberg - Zerfass, 2005; Röhrig, 2005; Zerfaß - Pfannenberg, 2005; Pfeffernkorn, 2009). Ez indokolja, hogy a klaszterek vonatkozásában is foglalkozzunk a témával.

Az érdektelenség közepette kivételnek lehet tekinteni a klaszterek marketingkommunikációjára irányuló kutatásokat (többek között Huttenloher, 2006; Kaminski, 2009; Lamprinopoulou et al., 2011; Felzensztein - Deans, 2013), továbbá a klaszterek kommunikációs eszköztárával foglalkozó tanulmányokat (Negruşa et al., 2014; Carbonara, 2005).

Több szerző foglalkozik azzal, hogy milyen szinteken dől el egy klaszter kommunikációja. A Bettina Blassini és munkatársai négy olyan "szintet" írnak le, amelyek egymással kölcsönhatásban állva befolyásolják a klaszter kommunikációját:

- az egyénből fakadó hatások (úgymint az egyén demográfiai jellemzői, énképe, a munkával kapcsolatos célja, iskolázottsága, kommunikációs készsége stb.,

- a szervezetből következő hatások (a munkakörülmények, irányítás, értékek, lehetőségek stb.),

- a klaszterből eredő hatások (a hálózat, a stakeholderek, az együttmüködés stb.),

- a kontextus hatásai, amihez történelmi, kulturális, politikai, gazdasági tényezők egyaránt tartoznak (Blassini et al., 2014, p. 129.).

A szerzők a kommunikáció funkcióját a következőkben látják:

- kapcsolatot és párbeszédet tesz lehetővé a klaszteren belül,

- kölcsönhatásokat vált ki a klaszter és a külső stakeholderek, illetve a klaszter és a külvilág között, és

- közös nyelvet hoz létre (Blassini et al., 2014, p. 129.).

Angsar Zerfaß (2005) arra hívja fel a figyelmet, hogy a kommunikátornak (a kommunikációmenedzsmentnek) nagy a szerepe a klaszter közös víziójának megosztásában, összeköti a klaszter belső és külső stakeholdereit egymással, létrehozza az együttmüködést.

Bernd Hartmann (2016) könyvében az extern kommunikáció áll a középpontban. Modelljében (Hartmann, 2016, p. 25.) a klaszter kommunikációja hármas stakeholder-csoportot érint: a klaszter a gazdaság, a politika és a tudomány szereplői kommunikációs terében él, befolyásolja azokat és függ is tölük. Területeiként a belső kommunikációt, a tudományos kommunikációt, az innovációkommunikációt, a nyilvánosságnak szóló marketinget, a telephely marketingjét, a politikai marketinget és a szövetségekkel folytatott kommunikációt emeli ki.

Empirikus kutatása nyomán arra a következtetésre jut, hogy a klasztermenedzsmentben nagyon alacsony a kifejezetten a kommunikációra specializálódott munkatársak aránya. Vagyis a klasztervezetés alulértékeli a kommunikációmenedzsmentet. Kis létszámú klasztervezetés esetén többnyire a klasztermenedzser is ellát kommunikációs 
feladatokat. A szerző megállapítja továbbá, hogy a nyugat- és észak-európai klaszterekben a kommunikációmenedzsmentnek nagyobb a stratégiai befolyása, mint a délés kelet-európai országokban.

Hartmann megállapítása szerint egy klaszter kommunikációmenedzsmentje számára kihívást jelent, hogy

- a klasztertagok eltérő igényekkel, elvárásokkal lépnek fel,

- a klasztertagok és más stakeholderek nem értik világosan a klaszterek komplexitását,

- szükösek a pénzügyi keretek, további kihívás

- a klasztervezetés kommunikációjának professzionálissá fejlesztése és

- a közösségi média bevonása a kommunikációs stratégiába.

A kommunikációmenedzsmentet leginkább befolyásoló tényezők: a finanszírozási forma, a klasztertagok száma, a klaszter életkora, a klaszter területlefedése és az iparág (Hartmann, 2016, p. 223-224).

\section{Klaszterkommunikáció egy empirikus kutatás tükrében ${ }^{2}$}

\section{Az empirikus kutatás}

A 2017 nyarán lezajlott kutatási projekt azt tárja fel, hogy egyes dél-dunántúli ipari klaszterek körében hogyan működik a belső kommunikációmenedzsment egyrészt a klasztermenedzsment és a klasztertagok között, másrészt klasztertag és klasztertag közt. Vizsgálja azt is, hogy a klaszterek, a klasztertagok sikerésségének vagy sikertelenségének érzetét befolyásolja-e a klaszteren belüli kommunikáció. A kutatás keresi a jó gyakorlati megoldásokat és igyekszik feltárni a nehézségek okát és megszüntetésük eszközeit. A gyakorlati megoldásokat a klaszter céljaival, stratégiájával és a klasztertagok által megélt sikerességgel vetjük össze.

A klaszterek sikerességének méréséhez más, hasonló kutatások keretében is megalkották saját definíciójukat a tárgykör kutatói: Lippert et al. (2015) háromdimenziós modellben értékelte a klasztermenedzsment eredményességét, ahol a szervezeti kultúra, a vezetői szerepek és a preferált célok alkották a magyarázó változókat és a magyarázott változók, vagyis a klasztersiker főbb komponensei a tagok elégedettségéből és a klaszter müködéséből állt, amelyet interjúkkal és kérdőíves lekérdezéssel vizsgáltak meg.

A siker, sikeresség szót interjúinkban pszichlógiai értelemben, azaz “élmény, ... tudatosan elérni kívánt, célul kitüzött hatás érdekében kifejtett fáradozás pozitív eredménye" jelentésben használtuk (Dorsch Lexikon der Psychologie: Erfolg). Vagyis a klaszter vontkozásában nem a teljesítménymutatókkal jellemezhető üzleti siker kimutatására törekedtünk, hanem az interjúalanyok által szub- jektíven megélt, a klaszterhez kötődő pozitív élmény meglétének vagy hiányának kiderítésére. Olyan élményeknek azonosítására, amelyek aktiválóan, a pozitív önértékelést elősegítően, a teljesítményt serkentően hatnak. Ezt azért is tartottuk fontosnak, mert az aktiváló hatás egyrészt mérhetö teljesítményben is megnyilvánul (Wiener, 1992; Heckhausen et al., 1998), másrészt a müvészi tevékenységek világában (amelyek a kreatív ipari klaszterek körébe tartoznak) a pozitív lelki élmények az üzleti sikernél fontosabbak lehetnek (ezt az interjúalanyok válaszai megerösítették). A tervezés során sikeres klaszternek azokat tekintettük, amelyekben a válaszadóknak legalább a fele sikeresként éli meg saját klasztere müködését (sikerül elérni azt az eredményt, amiért az erőfeszítés történik).

A kutatási projekt kérdése, hogy kimutatható-e összefüggés a klaszter célja és stratégiája, a klaszterben folyó kommunikáció intenzitása, tartalma, módja, formái, csatornái és eszközei, eredményessége, a kommunikációra ható sajátos klaszterjellemzők és a klaszter sikeressége között?

Hogy a kérdésekre választ kapjunk, félig strukturált interjúkat folyattunk három kiválasztott dél-dunántúli klaszter (egy gépipari, egy kreatív ipari és egy könnyüipari klaszter) vezetőivel, összesen 26 klasztertag-vállalat/ vállalkozás/intézmény vezetőjével, vagy kommunikációvezetőjével, továbbá a három klasztermenedzsment tagjaival. A 28, közel egy-egy órás interjúról részletes feljegyzéseket készítettünk. A kiértékelés szövegelemzéssel, azonos szempontok alapján történt.

A klaszterek kiválasztásához a Pécs-Baranyai Kereskedelmi és Iparkamara nyújtott segítséget a Dél-Baranyában müködő klaszterek társulásának listájával. Szándékunk volt a mintába nehéz-, könnyü- és szolgáltatóipari klasztereket egyaránt bevonni. Az így alkotott csoportokból véletlenszerűen választottunk ki először tizenkettőt, majd kapacitásaink korlátozottsága miatt, közülük egyetegyet, figyelve arra, hogy a kamara által eredményesen és kevésbé eredményesen müködőnek ítélt is bekerüljön a mintába.

\section{A Dél-Dunántúli Gépipari Klaszter}

A Dél-Dunántúli Gépipari Klaszter (DDGK) a szigorú gépipari normák világát testesíti meg. A gépipari 2011-ben alakult, a klaszter tagságát jelenleg 29 cég alkotja. Éves árbevétele 90-100 milliárd Ft, kb. 4-5000 föt foglalkoztat, és 60-70\%-os exportaránnyal müködik a klaszter, így gazdasági súlya országos szinten is mérhető. A szerveződés kifejezetten üzleti célok elérésére jött létre, és - a Pécs-Baranyai Kereskedelmi és Iparkamara (PBKIK) eröteljes közremüködésével - a részt vevő cégek összetételét tudatosan alakították ki. Ugyanakkor az alapítás alulról jövőnek is tekinthető, mert bár a PBKIK segített a koordinációban, és mai napig is komoly szerepet vállal a müködtetésben, a klaszter tagjai közötti munka nagyobb múltra tekint vissza. Ily módon a Dél-Dunántúlon mükö-

\footnotetext{
${ }^{2}$ A “Dél-dunántúl ipari klasztereinek kommunikációmenedzsmentje” címet viselő kutatási projekt a 2017. május és november közötti időszakban folyt a PTE KTK Szervezés- és Vezetéstudományi Intézete égisze alatt. A kutatás Borgulya Istvánné dr. egyetemi magántanár (kutatásvezető), dr. Balogh Gábor egyetemi adjunktus (kutató) és dr. Jarjabka Ákos egyetemi docens, intézetigazgató (szakmai projekttámogató) közreműködésével zajlott. Operatív tanácsadó szerepet játszott Rabb Szabolcs a Pécs-Baranyai Kereskedelmi ás Iparkamara titkára, a dél-dunántúli klasztertársulás vezetője.
} 
dő, egymással kiegészítő módon kooperáló gépipari cégek üzleti kapcsolatait szervezte klaszterbe a Kamara azzal az alapelvvel, hogy ne versengő, hanem komplementer szervezetek legyenek tagjai. A gépipari terület széles körü tevékenységlistát fed le, része például a gépészet, forgácsolás, gépgyártás, tervezés, telepítés, forgalmazás, értékesítés, beüzemelés.

A klaszter missziója: piaci együttmüködés, a klaszter belső piacának erősítése, közös kapacitáskihasználás, tapasztalat és információcsere platformjának kialakítása és müködtetése, az innovációs tevékenység dinamizálása, közös termékek kifejlesztése, a gépipari szakképzés fejlesztése, társulás az anyag, energia és a szolgáltatás beszerzésében, közös hazai és nemzetközi megjelenés és képviselet, közös erős lobbitevékenység kialakítása.

A cégek összetétele heterogén, és mivel a gépipar széles tevékenységi kört fed le, így a tagok méret és profil alapján is különböznek. A cégek képviselői nemcsak klaszterként tekintenek az együttműködési formára, hanem baráti társaságként is, azaz rendkívül fontos szerepet töltenek be a sikeres müködtetésben az emberi kapcsolatok. Egy-egy termékfejlesztési projektben általában 3-4 tag dolgozik együtt. Alaptevékenységüket tekintve sok beszállítói-vevői kapcsolat jellemzi a DDGK-t, és az erőforrásokban (föként emberi erőforrás) akár verseny is elképzelhető közöttük, de ez nem jellemző. A Dél-Dunántúlon rendelkezésre álló szakemberek száma igen szűkös, így ezen a területen egyrészt a szakképzés erősítésével igyekeznek könnyíteni a helyzeten, másrészt az információmegosztással ki is segítik egymást a tagok erőforrás-kapacitás hiány vagy felesleg esetén. A cégek közötti magas szintü bizalom lehetővé teszi, hogy a partnerszervezetek által ajánlott egy-egy szakember azonnal munkába állítható egy másik klasztertagnál, anélkül, hogy hosszadalmas és költséges kiválasztási folyamatot folytatnának le.

\section{A Kreatív Ipari Klaszter}

A pécsi központú Kreatív Ipari Klaszter (KIK) 2007ben, a gazdasági környezetet tekintve nehéz időszakban jött létre. Fő célja „A versenypiacon való sikeres müködés feltételeinek megteremtése, a kulturális innovációs hálózat és innovatív ágazati szereplök koordinált együttmüködésének megteremtése.”. Missziója: „a klasztertagok jövedelemtermelő képességének a fokozása" (KIK, 2018, o. n.). A részletezett célok között megtalálhatók többek között a "szakmai továbbképzések szervezése, a kulturális, kreatív ipar területén elért innovatív eredmények lehető legtöbb platformon történő kommunikálása, nemzetközi kapcsolatok építése".

Létrehozása baráti-szakmai szálakon alapult: az alapító tagok már az alapítást megelőzően is élő kapcsolatban álltak egymással. A kezdeményező, aki mindmáig a klaszter és a klasztermenedzsment elnöke, karizmatikus, alkotó szellemü, nagy tapasztalatú médiaszakember.

A klaszter ma, fennállása tízedik évében, négy nagy tevékenységi területet fog át: alkalmazott müvészetek, rendezvényszervezés, PR és kommunikáció, üzleti támogató tevékenységek.
A klaszter 38 klasztertagból áll, és megközelítően 600 föt érint a tevékenység. A tagvállalatokat, tagintézményeket, szervezeteket rendkívül nagyfokú heterogenitás jellemzi. A diverzitás megnyilvánul mind a foglalkoztatottak számában, mind a tevékenységi területekben, mind a szervezeti formákban, mind a vállalkozások, intézmények életkorában, mind forprofit, nonprofit tekintetben. A nagyon színes palettán megtalálhatók részben vagy teljes mértékben költségvetési intézmények és mikro-, kis-, közép- és egyéni vállalkozások. A tevékenységi körök a filharmóniai müvészeti munkától, a kamarai, az oktatási munkán át, a tervező, tanácsadó, közvetítő profilig, az egyedi, vagy szériatermékeket előállító cégek, illetve szolgáltató vállalkozások cselekvési területéig terjednek. A heterogenitást növeli, hogy a tagok a klaszterbe belépéskor vagy már több éves „elöélettel” bírtak, vagy éppen induló vállalkozások voltak. A klaszter legszembetünőbb jellemzője tehát a rendkívüli sokszínüség. A klasztertagok inkább kiegészítő, mint konkurens tevékenységet végeznek, a klaszteren belüli versengés gyenge. A klaszter müködése szempontjából nagyon pozitív az üzlettámogató szolgáltatást nyújtó (pl. consultinggel, innovációval foglalkozó) vállalkozások jelenléte, nagy szolgálatot tesznek a szakmai továbbképzés-célok megvalósításában. A kamara a klaszterben katalizátorként hat. Lényeges jellemző a pénzügyi önfenntartás. A forrásokat kis hányadban a klasztertagsági díj, túlnyomó részt a külső pályázatok képezik. A három fős menedzsment tehát nem csupán a klaszter céljainak megvalósításán dolgozik, hanem állandó pályázati tevékenységet is végez.

Az interjúk során megismert beszélgetőpartnerek közös feltűnő jellemzője személyiségük színessége, sokoldalúsága, a nagyfokú nyitottság, dinamikus lendület, kapcsolat a müvészetekkel.

Mindezek a körülmények alapvetően befolyásolják a klaszteren belüli kommunikációs infrastruktúra és a kommunikációs kultúra jellemzőit és a kommunikáció minőségét.

\section{A Pécsi Kesztyü Klaszter}

Az előzőekben bemutatott két sikeresen müködő klaszterrel szemben a Pécsi Kesztyü Klaszter (PKK) az ellenpólust képviseli. A nagy múlttal rendelkező kesztyüs iparág a '90-es években 29 céget jelentett, melyből mára 6 cég maradt, ami azt jelenti, hogy 5 ezer föből napjainkban mintegy 500 föt foglalkoztat a hazai pécsi kesztyüs ágazat. Tagdíj nincs a kesztyü klaszterben. Az alacsony taglétszám ellenére a müködő cégek kapcsolata nem kooperatív, éppen ellenkezőleg, versengő. A cégprofilok összetétele homogén, hasonló tevékenységgel, azonos beszállítói és vevői körrel rendelkeznek, így egymás versenytársai. Mindezt a kapcsolatrendszert bizalomhiány terheli.

\section{Kutatási eredmények}

Kutatási kérdésünket három részkérdésre bontottuk:

1. Sikeresnek ítélik-e a klasztertagok a klaszter müködését vagy nem? 
2. Milyen célt és stratégiát követve irányítja a klasztervezetés a klasztert, hogy sikerre juttassa azt?

3. Hogyan állítja a klasztervezetés a kommunikációmenedzsmentet a célok elérése és a stratégia megvalósítása szolgálatába?

Az interjúk során feltárt jellemzőket háromelemü vizsgálati modelünk alapján mutatjuk be: a sikeresség - a klasztercél és klaszterstratégia - kommunikációmenedzsment (1. ábra).

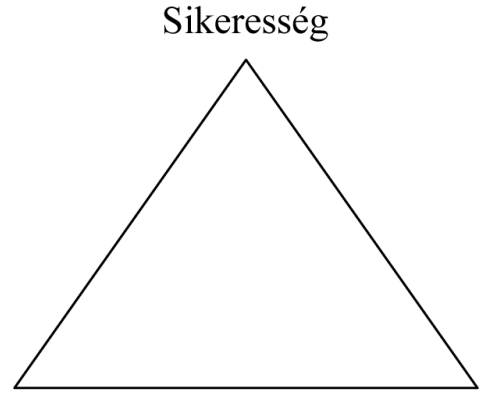

Klasztercélok és
klaszterstratégia

Kommunikációmenedzsment

\section{1. ábra Az empirikus kutatás komponensei és összefüggésük (saját szerkesztés)}

A sikerességet az előzőekben leírtak alapján hasonlítjuk össze a három klaszterben. A klasztercélról és a klaszterstratégiáról a klasztervezetőkkel folytatott interjúk, illetve a nyomtatott és elektronikus klaszterismertetők szolgáltattak információkat. A kommunikációmenedzsment müködésének megismerésében a klasztertagokkal és klasztervezetőkkel készített interjúk során elhangzott leírásokra és értékeléseikre támaszkodtunk.

\section{Sikeresség}

A három vizsgált klaszter közül kettőben nagyon pozitív a kép: válaszadók döntő többsége sikeresnek, illetve abszolút sikeresnek minősíti saját klaszterét, mindössze néhány kiegészítő vélemény hangzott el arra vonatkozóan, hogy hogyan lehetne továbbfejlődni ("Sikeres, de..."). A harmadik klaszter interjúalanyai viszont nem találják a saját klaszterüket sikeresnek.

Fontos kérdés volt, hogy a megkérdezettek mit tekintenek a sikeresség mércéjének a klaszter müködésében $(1$. táblázat). Mindhárom klaszterre igaz, hogy sikerkritériumként fogalmazódik meg, hogy a klasztertagok együttmüködésével a közös ügyeket, problémákat hatékonyabban tudják vagy tudnák megoldani, mint külön-külön: információk, ötletek és tapasztalatok megosztása, segítségnyújtás, inspiráció. Ugyanakkor a sikeresség mércéjét a három klaszter más aspektusból értelmezi: a gépipari klaszter konkrét üzleti eredményeket vár a klaszter müködésétől (beszállítói és erőforrások kapacitás kihasználása, beszerzések stb.), a KIK esetében a közös problémamegoldások és az ismertség állnak az élen, míg a kesztyü klaszternél elsősorban marketingcélokat fed le az együttműködés.

\begin{tabular}{|c|c|c|}
\hline Gépipari klaszter & $\begin{array}{l}\text { Kreatív ipari } \\
\text { klaszter }\end{array}$ & Kesztyús klaszter \\
\hline $\begin{array}{l}\text { Elért eredmények, } \\
\text { kitűzött célok } \\
\text { megvalósítása, pl. } \\
\text { együttműködés } \\
\text { a képzésben, közös } \\
\text { üzemanyag beszerzés, } \\
\text { lobbieró stb. }\end{array}$ & $\begin{array}{l}\text { A problémák } \\
\text { közös } \\
\text { megoldásának } \\
\text { sebessége }\end{array}$ & $\begin{array}{l}\text { Marketing- és } \\
\text { médiamegjelenésel } \\
\text { száma } \\
\text { (reklám és } \\
\text { nyilvánosság } \\
\text { fókusz) }\end{array}$ \\
\hline $\begin{array}{l}\text { Akkreditáció + eszmei } \\
\text { érték (elnyert díjak, } \\
\text { pozitív imázs, büszkeség) }\end{array}$ & $\begin{array}{l}\text { A klasztertagságnak } \\
\text { köszönhető } \\
\text { problémamegoldások } \\
\text { száma }\end{array}$ & $\begin{array}{l}\text { Márkabolt } \\
\text { müködése }\end{array}$ \\
\hline $\begin{array}{l}\text { Kommunikáció } \\
\text { gyakorisága, hatékonysága }\end{array}$ & $\begin{array}{l}\text { A közös nyilvános } \\
\text { rendezvények } \\
\text { száma }\end{array}$ & \\
\hline Elégedettségmérések & $\begin{array}{l}\text { Az együtt } \\
\text { megjelenésből } \\
\text { eredö ismertség }\end{array}$ & \\
\hline
\end{tabular}

1. táblázat A sikeresség mércéje (saját szerkesztés)

Arra is fény derült, hogy miért tartják érdemesnek, hasznosnak a klasztertagságot a vállalatok (2. táblázat).

\begin{tabular}{|c|c|c|}
\hline Gépipari klaszter & $\begin{array}{l}\text { Kreatív ipari } \\
\text { klaszter }\end{array}$ & Kesztyüs klaszter \\
\hline $\begin{array}{l}\text { Ügyfelek és } \\
\text { partnerek } \\
\text { megkeresései }\end{array}$ & $\begin{array}{l}\text { Emberi-szakmai } \\
\text { közösségérzést ad }\end{array}$ & $\begin{array}{l}\text { Közös fesztivál } \\
\text { szervezése (150 éves } \\
\text { ünnepség kapcsán) }\end{array}$ \\
\hline $\begin{array}{l}\text { Együttműködések } \\
\text { létrejötte, hasznos } \\
\text { szinergiák, } \\
\text { kapcsolatok } \\
\text { kialakítása }\end{array}$ & $\begin{array}{l}\text { Problémafelvető és } \\
\text { problémamegoldó } \\
\text { közösség }\end{array}$ & Márkabolt \\
\hline $\begin{array}{l}\text { Képzési lehetőségek } \\
\text { (duális képzés) }\end{array}$ & $\begin{array}{l}\text { Remek, ötletelő } \\
\text { légkör }\end{array}$ & Közös weboldal, logó \\
\hline Anyagi előnyök & $\begin{array}{l}\text { Tudásmegosztó } \\
\text { szerveződés }\end{array}$ & Közös projektek \\
\hline $\begin{array}{l}\text { Nincs konkurencia } \\
\text { a klaszteren belül, } \\
\text { kiegészítő jellegü } \\
\text { kapcsolatok vannak }\end{array}$ & $\begin{array}{l}\text { Gyors, megbízható és } \\
\text { szerteágazó } \\
\text { informálódás } \\
\text { (pályázatokról, } \\
\text { eseményekről) }\end{array}$ & $\begin{array}{l}\text { „Összehozta } \\
\text { a kesztyüs } \\
\text { társadalmat" }\end{array}$ \\
\hline $\begin{array}{l}\text { Kapacitások } \\
\text { szétosztása egy-egy } \\
\text { projektben }\end{array}$ & $\begin{array}{l}\text { Egyfajta klubélet - } \\
\text { jó hangulatú } \\
\text { összejövetelek }\end{array}$ & $\begin{array}{l}\text { Erősíti a kapcsolatot, } \\
\text { a klaszterszerződés } \\
\text { miatt bátrabban } \\
\text { keresik meg egymást }\end{array}$ \\
\hline $\begin{array}{l}\text { Közös beszerzés } \\
\text { (üzemanyag) }\end{array}$ & $\begin{array}{l}\text { Kapcsolati tőkét } \\
\text { biztosít }\end{array}$ & $\begin{array}{l}\text { Anyagbeszerzés, } \\
\text { közös rendelések }\end{array}$ \\
\hline $\begin{array}{l}\text { Információáramlás, } \\
\text { munkaerő-adatbázis, } \\
\text { közös kiadványok } \\
\text { (portfolió) }\end{array}$ & $\begin{array}{l}\text { Segíti az induló } \\
\text { vállalkozások } \\
\text { fejlődését }\end{array}$ & $\begin{array}{l}\text { Képzési } \\
\text { együttmüködés }\end{array}$ \\
\hline $\begin{array}{l}\text { Közös piacra lépés, } \\
\text { közös fejlesztések }\end{array}$ & $\begin{array}{l}\text { Segíti a marketing- } \\
\text { tevékenységet }\end{array}$ & \\
\hline $\begin{array}{l}\text { Tapasztalatcsere, } \\
\text { tudás átadása, } \\
\text { benchmarking }\end{array}$ & Növeli az ismertséget & \\
\hline $\begin{array}{l}\text { Vásári és kiállítási } \\
\text { megjelenések }\end{array}$ & $\begin{array}{l}\text { (Nemzetközi) } \\
\text { pályázat lehetősége }\end{array}$ & \\
\hline
\end{tabular}

\section{2. táblázat A klasztertagságból származó előnyök (saját szerkesztés)}

Mindhárom klaszternél érzékelhető előny a közösségszerveződés, bár ez elsősorban a gépipari és a kreatív ipari klaszternél volt sikeres: a közösség élménye, baráti légkör, oldott hangulat, kapcsolatépítés, információmegosztás, tapasztalatcsere. Szintén közös előnyként értelmezhetők 
a vásári megjelenések, pályázati lehetőségek és az ismertség növelése. A gépipar területén specifikusan kiemelték a következőket: nincs konkurencia (komplementer kapcsolatok), kapacitások közös szétosztása, közös piacralépés és akkreditáció. A kreatív ipari klaszternél az egymást inspiráló interakciókból fakadó új, innovatív gondolatok generálása az egyik legnagyobb elöny, míg a kesztyü klaszternél azok az eredmények sorolhatók ide, amelyeket a tagok önmagukban nem tudtak volna elérni: márkabolt, vásári kiállítás, könyv, „Magyar termék” titulus.

A KIK-ben a megnevezett előnyök között megemlítik a válaszadók, hogy a tagok kisebb kedvezményeket is adnak egymásnak (pl. alacsonyabb nyomdaköltség, kedvezményes belépőjegy stb.), azonban valamennyi interjúalany a közösségi összetartozást emeli ki. A klaszter üzleti erejének növelése ugyan kívánatos lenne, de megvalósulását számos akadály nehezíti. A klaszteren belül müködő üzletek, közös projektek, külső projektekben közös fellépések gátja, hogy az többéves múlttal rendelkező tagok már kiépített kapcsolati hálóval léptek be a klaszterbe, e kapcsolatokat nem akarják gyengíteni a tagság következtében; bár szerteágazó a tagok tevékenysége, üzleti tekintetben nem kapcsolhatók össze e tevékenységek, továbbá, ahhoz túl kicsi az átfedés a tagok között, hogy versenyhelyzetet teremtene.

A gépipari klaszter számára a klaszterbe szerveződés legnagyobb pozitívumai: a szakképzésben elért eredmények (duális képzés, képzési lehetőségek) és a szakmai kapcsolatok kialakítása, amely lehetőséget teremt a régi és az új tagokkal való ismerkedésre, hasznos szinergiák kialakítására. Az interjúalanyok leszögezték, hogy a klasztertagságból származó előnyöket közvetlenül nehéz számszerüsíteni. Rövid távon, pénzügyi szempontból nem mindenkinek éri meg a tagság, de - még a magas tagdíjjal együtt is - hosszú távon, a kapcsolatokból fakadó közvetett elönyök, a tapasztalatcsere, az információmegosztás, a közös fellépésből származó gazdasági és lobbierő és ezek tovagyürüző hatása miatt egyértelmủen megéri a klaszterhez tartozni. Mérhető előnyök: közös beszerzések (pl. 10-15\%-os árengedmény az üzemanyagoknál). További fontos eredmények, hasznok:

- akkreditált klaszterminősítés, ami a EU-s pályázatokhoz is fontos szempont,

- kapacitások, projektek, erőforrások szétosztása, információáramlás és -megosztás,

- közös piacra lépés, közös fejlesztések, beszerzési árak csökkentése,

- tapasztalatcsere (benchmarking klubok), vásári és kiállítási megjelenések, állásbörze,

- közös kiadványok (portfólió), közös sikerek, díjak közzététele, megünneplése,

- ha megtalálják a közös témát, rászánják az idejüket a résztvevők,

- lobbi és ágazati készségtanács, duális képzés elindulása,

- eszmei (presztízs) érték, büszkeség, szakmai és baráti közösség.

A Pécsi Kesztyű Klaszter elsősorban a márka (brand) közös építését, népszerüsítését helyezte a középpontba, és a tagok arról számoltak be, hogy tagdíj hiányában a klaszter létezése hátrányokkal nem járt, sőt mérsékelt sikereket a korábbiak során sikerült is elérni a marketing területén, mint a fesztivál szervezése, közös kiadvány, a „Magyar termék" minősítés. Azaz a résztvevők annak ellenére is hasznosnak találják a klaszter müködését, hogy az utóbbi időben tényleges együttmüködést nem sikerült megvalósítani.

\section{Klasztercélok és klaszterstratégia}

A célközpontú vezetés (Drucker, 1954) elve alapján egy szervezet tagjai akkor élhetnek meg a szervezet müködéséhez kapcsolódó sikert, ha azonosulnak a szervezet céljaival, ha a célok a saját elérni kívánt szándékaikkal összhangban vannak. Erőfeszítésre akkor motiváltak, ha megértik és elfogadják a vezetés által kezdeményezett, a célhoz vezető stratégiai lépéseket. Ahhoz, hogy ez megvalósulhasson, megfelelő kommunikációra van szükség.

\begin{tabular}{|c|c|c|c|}
\hline \multirow{3}{*}{ Célok } & Gépipari klaszter & $\begin{array}{l}\text { Kreatív ipari } \\
\text { klaszter }\end{array}$ & $\begin{array}{l}\text { Kesztyús } \\
\text { klaszter }\end{array}$ \\
\hline & $\begin{array}{l}\text { Piaci } \\
\text { együttmüködés }\end{array}$ & $\begin{array}{l}\text { A régió kreatív } \\
\text { ágazatainak } \\
\text { összefogása, } \\
\text { szereplőinek } \\
\text { támogatása }\end{array}$ & $\begin{array}{l}\text { Közös } \\
\text { marketing- } \\
\text { megjelenések }\end{array}$ \\
\hline & $\begin{array}{l}\text { A klaszter belső } \\
\text { piacának erősítése, } \\
\text { közös kapacitás- } \\
\text { kihasználás }\end{array}$ & $\begin{array}{l}\text { A klasztertagok } \\
\text { jövedelem- } \\
\text { teremtő } \\
\text { képességének } \\
\text { fokozása }\end{array}$ & $\begin{array}{l}\text { Közös weboldal } \\
\text { és logó } \\
\text { használata }\end{array}$ \\
\hline \multirow[t]{3}{*}{ Misszió } & $\begin{array}{l}\text { Tapasztalat és } \\
\text { információcsere } \\
\text { platformjának } \\
\text { kialakítása és } \\
\text { múködtetése }\end{array}$ & $\begin{array}{l}\text { Tudásmegosz- } \\
\text { tás és } \\
\text { tudásfejlesztés }\end{array}$ & $\begin{array}{l}\text { Közös márkabolt } \\
\text { kialakítása }\end{array}$ \\
\hline & $\begin{array}{l}\text { Az innovációs } \\
\text { tevékenység } \\
\text { dinamizálása, } \\
\text { közös termékek } \\
\text { kifejlesztése }\end{array}$ & $\begin{array}{l}\text { A kulturális, } \\
\text { kreatív ipar } \\
\text { területén } \\
\text { elért innovatív } \\
\text { eredmények } \\
\text { megosztása }\end{array}$ & $\begin{array}{l}\text { Hagyományőrzés, } \\
\text { kulturális értékek } \\
\text { feltárása }\end{array}$ \\
\hline & $\begin{array}{l}\text { A gépipari } \\
\text { szakképzés } \\
\text { fejlesztése }\end{array}$ & $\begin{array}{l}\text { Külföldi } \\
\text { klaszter- } \\
\text { kapcsolatok } \\
\text { építése }\end{array}$ & $\begin{array}{l}\text { Közös kiadvány } \\
\text { szerkesztése } \\
\text { (könyv) }\end{array}$ \\
\hline \multirow{4}{*}{ Stratégia } & $\begin{array}{l}\text { A további } \\
\text { ágazatokkal és } \\
\text { klaszterekkel való } \\
\text { szakmai } \\
\text { kapcsolatrendszer } \\
\text { kialakítása }\end{array}$ & $\begin{array}{l}\text { Klaszteren } \\
\text { belüli szakmai } \\
\text { képzések, } \\
\text { speciális } \\
\text { kurzusok, } \\
\text { fórumok } \\
\text { szervezése }\end{array}$ & $\begin{array}{l}\text { Közös } \\
\text { anyagbeszerzés }\end{array}$ \\
\hline & $\begin{array}{l}\text { Társulás az anyag, } \\
\text { energia és } \\
\text { a szolgáltatás } \\
\text { beszerzésében }\end{array}$ & $\begin{array}{l}\text { Pályázatok } \\
\text { támogatása }\end{array}$ & \\
\hline & $\begin{array}{l}\text { Közös hazai és } \\
\text { nemzetközi } \\
\text { megjelenés és } \\
\text { képviselet }\end{array}$ & $\begin{array}{l}\text { Részvétel } \\
\text { külföldi } \\
\text { tapasztalat- } \\
\text { cseréken }\end{array}$ & \\
\hline & $\begin{array}{l}\text { Közös erős lobbi } \\
\text { tevékenység } \\
\text { kialakítása }\end{array}$ & & \\
\hline
\end{tabular}

3. táblázat Klasztercélok és klaszterstratégiák (saját szerkesztés, a DDGK honlapjának felhasználásával (letöltve: http://www.ddgk.hu/ (2018.04.06.)) 


\section{Dél-Dunántúli Gépipari Klaszter célja és stratégiája}

A megkérdezettek értékelése alapján a gépipari klaszter a régió legoperatívabb klasztere: racionális, erős csoportosulás, kevésbé eszmei vagy elméleti a célja. A tagok közötti viszony demokratikus, és az interjúalanyok szerint önmagában egyik cég sem lenne elég erős ahhoz, hogy lobbierőként lépjen fel. Időnként egy-egy cég dominánsabbá válhat, ez a feladattól függő aktívabb szerepvállalást jelent. Alapesetben évente van tisztújítás a DDGK-ban, azonban egy-egy nyertes pályázat teljes „lemenedzselése” miatt ez akár 4-5 éves periódust is jelenthet. Ez biztosítja, hogy egyik elnök cége se dominálja a klasztert. Az alapítók és a jelenlegi tagság „elitklubként” szeretnék megörizni a klasztert (szigorú belépési kritériumok a névleges tagság kiszüréséhez). Az „elitklub” ugyanakkor nem azt jelenti, hogy a klaszter a gazdag cégek klubja: bár az éves tagdíj magasnak mondható (több százezer Ft), a kisebb, de aktív cégek kérvényezhetik a tagdíj egy részének elengedését. Cél a klaszter nívójának, presztízsének megőrzése.

\section{A Kreatív Ipari Klaszter céljai és stratégiája}

Mint láttuk, a kreatív ipari klaszter tagjai sikerként élik meg a közös szakmai erőfeszítéseket: a kölcsönös segítést a problémák megoldásában, a társadalmi tőke, a tudás megosztását, közös forrásszerzést. Más szóval szakmailag segítő közösségre vágynak. A klasztervezetés céljai: összefogni az ágazat szereplöit és megteremteni a koordinált együttműködést, külföldi kapcsolatokat építeni (3. táblázat). A tagok tehát megtalálják a klaszter céljában azt, aminek megvalósulása sikerérzéshez juttatja őket. A célok, a misszió és a stratégiai lépések: a tudásmegosztás megszervezése (speciális kurzusok tartása a klaszter tagjainak, megfelelő fórumok megteremtése, külföldi tapasztalatcsere) összhangot képeznek.

\section{A Pécsi Kesztyü Klaszter célja, stratégiája}

A klaszter eredeti célja a közös megjelenés (logó, marketing, reklámanyagok, fesztiválok, értékesítés stb.), a fogyasztók irányában történő együttes fellépés, amellyel a pécsi kesztyủ márkáját (brandjét) kívánták erősíteni. A klaszter indulásakor több együttműködés, közös projektek, beszerzési és munkaerö-piaci kooperációk folytak. Mára azonban a szükülő piaci környezet, a generációs problémák és a kollaborációs attitüdök megváltozásával a tagok egyre inkább egymás vetélytársai lettek, és már nem fektetnek hangsúlyt a közösen elérendő célokra, inkább kiszorítani igyekeznek egymást a szük piacokon. Nem áll érdekükben az együttműködés, többé nincs közös akarat, ami a klaszter tényleges és hatékony müködésének fenntartását célozná.

A három klaszter hasonló misszióval rendelkezik: tudásmegosztás, együttműködések kialakítása, megjelenés erősítése belföldön és külföldön, a jövedelemtermelő képesség növelése, innováció facilitálása, (ez utóbbi a kesztyü klaszter esetében nem szerepel a célok között). A küldetés eléréséért megfogalmazott stratégiák elsősorban az iparági sajátosságok miatt különböznek: a konkrét megvalósítás a gépipar területén az energiabeszerzésre, a munkaerő képzésére és a termelési-beszállítói hálózat- ra, kapacitásokra és erőforrásokra összepontosít. A képzés és az erőforrás-kihasználás a kesztyű klaszternél is fontos stratégia lenne, de érdekütközések, konkurálás és szűk piaci mozgástér miatt ezek megvalósítása nehézségekbe ütközik. A kreatív ipari klaszternél erőteljesebb a tagok önképzése, a külföldi (nemzetközi) és a pályázati fókusz.

\section{Kommunikációmenedzsment}

\section{A kommunikáció bemutatása az interjúk tanulságát foglalja össze.}

\section{A Dél-Dunántúli Gépipari Klaszter A kommunikáció iránya}

A klaszterkommunikáció kétirányú: egyrészt a KLM irányából központi jellegü (elektronikus üzenetek formájában), így minden KLT értesül a közös ügyekröl. Másrészt a tagok közötti, kevesebb tag bevonásával jellemezhető konkrét munkát elektronikusan, telefonon és személyesen végzik a cég képviselői. Fontos kiemelni a generációs kérdést: az idősebbek a telefont, míg a fiatalabbak az elektronikus formát preferálják. A telefon és email közötti választás személyiség és habitus kérdése is, a régi KLT-k és a menedzsment nagyjából tisztában van azzal, hogy kivel melyik csatornán lehet a leghatékonyabban kapcsolatot teremteni. A kommunikáció müködését a fenti folyamatok biztosítják, így az nem kötődik egyegy domináns céghez vagy személyhez. Mivel a klaszter fenntartása minden tag számára extra feladat, így egy-egy KLT ideiglenesen inaktívvá válhat - saját üzletmenete időszakos túlterhelődése esetén.

\section{Csatornák és eszközök a kommunikáció tartalma}

A gépipari klaszternél alapvetően három kommunikációs csatorna müködik: a benchmark találkozók, az elektronikus csatornák és a telefon.

Közvetlen személyközi kommunikáció: benchmark rendezvények. Ezeken a találkozókon a klaszter közös ügyeit tárgyalják meg, itt alakítanak ki új kapcsolatokat, és mélyítik el a régebbi együttműködések. A találkozók egy-egy elöre meghatározott témával foglalkoznak. Céljuk egyúttal az is, hogy megismerjék egymás cégét, így a helyszín változó. Jellemző ugyanakkor, hogy minél távolabb van a meeting a régió központtól (Pécs), annál alacsonyabb a részvételi arány. A fentieken túl távolabbi benchmark látogatásokat is szerveznek (például egy alapvetően más gazdasági környezetben, igen jól müködő, linzi központú osztrák gépipari klaszternél).

Elektronikus csatornák: tartalmuk tájékoztató (pl. vásári információk, gazdasági hírek, törvényi változások, új rendeletek, benchmarking ülések, kapacitás-, anyagtöbblet és -hiány) vagy felhívás jellegű (pl. segítségre, együttműködésre). Az esetek többségében a menedzsmenthez befutó igények, kérések, információk megosztása történik központilag, amelyröl minden tag értesülhet, majd azok a tagok folytatják a konkrét együttmüködést, akik be tudnak kapcsolódni az adott munkába. Ez a további szál gyakran telefonon folytatódik. 
A telefonos kommunikáció általában az elektronikus információgyüjtést követő, konkrét, adott partnerek közötti operatív munka megkezdéséhez, lefolytatáshoz használt csatorna.

\section{Gyakoriság és involváltság}

Az interjúalanyok válaszai alapján a következő gyakorisági sorrendet lehetett felállítani az összesített adatokból: leggyakrabban az e-mailt használják, ezt követi a telefon, majd a személyes találkozók és közös klaszterrendezvények.

\section{Preferált kommunikációs formák és azok eredményessége}

Az interjúalanyok többsége leszögezte, hogy a leghasznosabb együttműködési forma a személyes egyeztetés, amire a benchmark rendezvényeken is lehetőségük van. A válaszadók jelzései alapján nagyon hasznosak ezek a találkozók. Az új tagok beilleszkedését segítendő kialakítottak egy klasztertablót, ahol archoz tudják kötni a neveket. A találkozó egyik sajátos problémája, hogy nem mindig ugyanazok a személyek vesznek részt a találkozókon: a nagyobb cégek az adott meeting témájához leginkább kapcsolódó szakembert küldhetik a cégvezető helyett, a kisebb cégek vezetői pedig nem minden találkozón tudnak jelen lenni személyesen. Ez megnehezíti a részvételt a folyamatos munkában. A legnagyobb probléma az idő hiánya. Ennek ellenére a klasztertalálkozók előkelő helyet foglalnak el a cégvezetők naptárjában is.

Az elektronikus csatornák használata kapcsán a megkérdezettek az alábbi jellemzőkről nyilatkoztak:

- minden tag gyorsan reagál, nem zavaró, van nyoma, gyors, közvetlen, rövid,

- mindenki tud egy adott kérdésröl, és utána már csak a közvetlenül érintettek egyeztetnek tovább személyesen vagy telefonon,

- kötetlen, nem formalizált.

Előfordul, hogy egy-egy érintett nem reagál a kör emailekre, a KLM azonban nem hagyja a folyó ügyeket „elsikkadni”, hanem újra és újra emlékezteti a tagokat a reagálásra, egymás igényeinek kiszolgálására.

Telefonos kommunikáció: annak ellenére, hogy gyakran alkalmazott kommunikációs forma a telefonálás, érzékelhetően megvannak a korlátai: nehezítő körülmény, hogy mindkét fél egy időben ráérjen, illetve nem visszakereshetők az elhangzottak.

\section{A kommunikációt befolyásoló sajátos klaszterjellemzők}

Az interjúalanyok szerint a gépipari klaszter gazdasági súlya nagy, ám a lobbierő tekintetében megoszlanak a vélemények: lokálisan van hatása (munkaerőpiac, szakképzés), ugyanakkor régiós szinten nincs még elegendö infrastrukturális lobbiereje (pl. ipari méretű közlekedés és autópálya). A megkérdezettek mindegyike kiemelte a Déldunántúli régió és azon belül is Baranya megye alacsony szintü gazdasági teljesítményét, ami alapvetően megnehe- zíti a cégek és a klaszter müködését a régióban. Részben a gazdasági környezet által támasztott nehézségek kiküszöbölésére is jött létre a klaszter.

\section{A klasztertagok véleménye a klaszteren belüli kommunikációról}

Az interjúalanyok szerint a kommunikáció intenzitása optimális: „a csatornák megvannak, ha akarjuk, megtaláljuk egymást. Azért, hogy eggyel több e-mail legyen, azért nincs szükség intenzívebb kommunikációra”, valamint „,ennél intenzívebb kommunikáció már túl sok lenne, mert nem a cégek vannak a klaszterért, hanem a klaszter van a cégekért." A KLM erőssége, hogy félreértések vagy meghiúsult kooperációk esetén túl tudja lendíteni az ügyeket a holtponton: „egy körrel többre ad lehetőséget".

\section{Kreatív Ipari Klaszter}

\section{A kommunikáció iránya}

A belső kommunikáció egyrészt a klasztermenedzsment (KLM) és a klasztertagok (KLT) között zajlik. Lehet váltakozóan egyirányú vertikális (például a KLM rendszeresen küld a tagoknak hírlevelet, illetve a KLT-k kezdeményezik információ megosztását), lehet kétirányú (e-mail-váltások, a telefonok, a közvetlen személyközi kommunikáció), lehet horizontális (a KLT-k egymás közötti kommunikációja). Míg a KLM és a KLT-k közötti kommunikáció centralizált és több formális kötöttséget is tartalmaz(hat), a KLT-k egymás közötti üzenetváltásai hálózatosak, csakúgy mint a gépipari klaszter esetében (2. ábra).

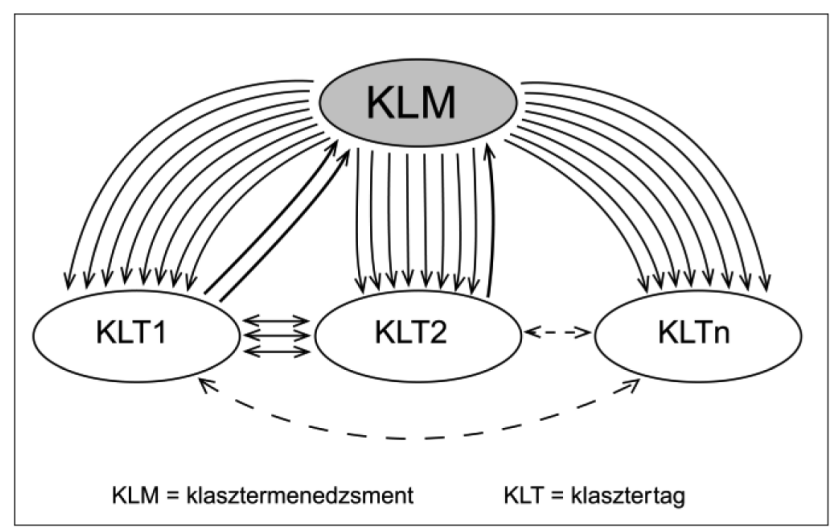

2. ábra A klasztermenedzsment és a klasztertagok kommunikációja a gépipari és a kreatív ipari klaszternél (saját szerkesztés)

\section{Csatornák, eszközök és a kommunikáció tartalma}

Az üzleti kapcsolattartásban leggyakrabban használt az elektronikus csatorna, kialakult az elektronikus klaszterközösség, de a közösségi média nem tartozik a klaszter müködtetett csatornái közé. A KLM $\rightarrow$ KLT irányú kommunikációkezdeményezés a legintenzívebb (évi 40-60). Az e-mailek leggyakoribb tartalma: információterítés eseményekről (meghívók, tudósítások), beszámo- 
ló a klaszter eseményeiről (formája Hírlevél), közvetítés a tagoktól érkező kérdések, problémák megoldásában, felajánlásokban, adatkérés beszámolókhoz. A KLT-k visszajelzésének intenzitása elmarad a KLM aktivitása mögött. A menedzsmentnek olykor többször meg kell ismételnie az adatkérést. A KLT-k ritkábban kezdeményeznek kommunikációt a menedzsmenttel (átlagban évi háromszor-ötször tagonként) Az elektronikus levelezés mellett a leggyakrabban használt kommunikációs eszköz a telefon. (Ez a tény azért figyelemreméltó, mert az egyébként innovatívan gondolkozó klasztertagok e tekintetben konzervatívak, teljesen hiányoznak az eszköztárból a belső kommunikációs platformok, az intranet, a chat-típusú megoldások, a közösségi média adta lehetőségek.)

A tagok egymás közötti eszközkötött hálózatos kommunikációja (mind e-mailben, mind telefonon) gyér. Egy-egy KLT általában négy-öt másik klasztertaggal áll kapcsolatban, rendszerint egy-egy megbízás közös megvalósítása céljából. A klaszteren belül tehát a menedzsmentközpontú kommunikáció erőteljes, dominál a KLM $\rightarrow$ KLT irány. A hálózatos elektronikus és telefonos kapcsolatok gyengék.

\section{Gyakoriság és involváltság}

A klasztertagokra vetített üzenetváltások száma nem egyenletes eloszlású. Vannak KLT-k, amelyek sok saját klaszteren belüli taggal állnak folyamatosan kapcsolatban, sürüsödések, csomópontok alakulnak ki az üzenetváltások hálózatán. Más KLT-k klaszteren belüli kommunikációja kevés KLT-ra korlátozódik. Jellemző, hogy nem feltétlen az üzletileg legerősebb KLT-k jelentik a kommunikációs csomókat. Például egy kis nyomdaipari vállalkozás is állhat számos klasztertaggal kapcsolatban azok folyamatos megrendelései (3. ábra).

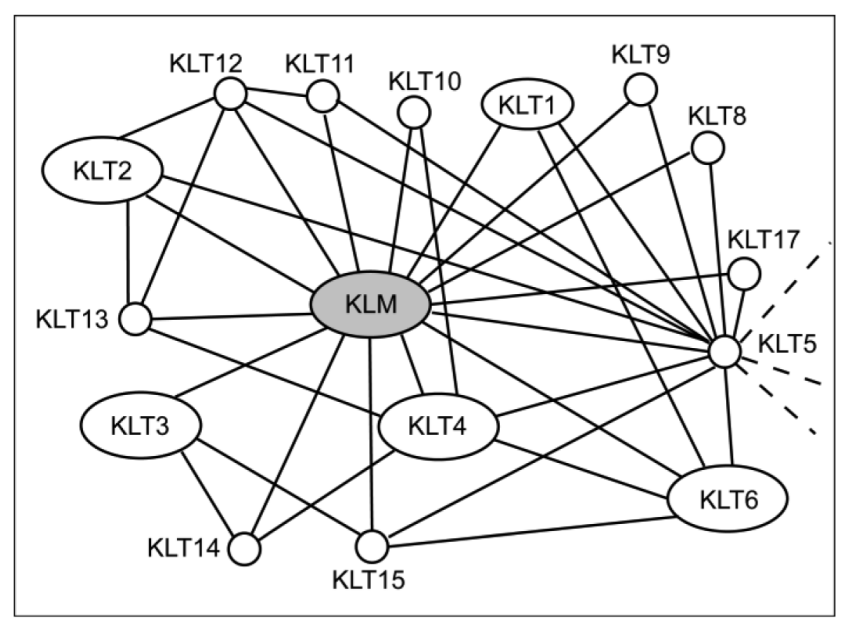

3. ábra A kommunikációban részvétel tagonkénti eloszlása Jelmagyarázat: $\mathrm{KLT}=$ klasztertag; $\mathrm{KLM}=$ klasztermenedzsment (saját szerkesztés)

\section{Preferált kommunikációs formák és azok eredményessége}

\section{Közvetlen személyközi \\ kommunikáció}

A belső kohézió építésében, a közösségi összetartás erösítésében a közvetlen személyközi kommunikáció, a személyes találkozások a döntő fontosságúak. E tekintetben a Kreatív Ipari Klaszter rendkívül aktív. A KLM székhelye a Co-Working House (KOHO) a KLT-k rendszeres találkozásának színhelye: iroda, tárgyaló, képzési színtér, közösségi tér. A KOHO összetartó tényezö, a klaszter otthona. A KLT-k a személyes találkozásokat tartják a klaszter kötőelemének.

\section{Klaszterreggeli}

A kötetlen programmal rendszeresített klaszterreggelik a leghasznosabb informális találkozások. Havonta egyszer a KOHO-ban találkoznak a tagok. Az egyszerü reggeli keretében spontán felmerülő szakmai témákról folyik a beszélgetés. Hozadéka, hogy széles körű új, megbízható információhoz lehet hozzájutni; csapatépítés történik, közös problémamegoldások, brain stormingok, nagy ötletelések zajlanak.

\section{Közös piknik, „rapid randi”, kölcsönös céglátogatás}

Hasonló kötőerőt jelentenek a közös ,piknikek”, a grillezös beszélgetések a KOHO melletti füves területen. A "rapid randi" az új tagok megismerését segíti. A belépő tagok egyenként mutatkozhatnak be a régiknek rövid beszélgetés keretében, keresve a közös kapcsolódási pontokat. Egymás vállalkozásának meglátogatása nem csupán az élő kapcsolattartás eszköze, hanem benchmark szerepe is van. E programok keretében ismerik meg a tagok kölcsönösen egymás tevékenységének részleteit.

\section{Képzések és közös nyilvános fellépések}

A közös képzések belső igényeket elégítenek ki, és elsősorban az üzleti ismeretek gyarapítását szolgálják. Mivel az előadók többnyire a klaszteren belülről kerülnek ki, alacsony költséggel megszervezhetők. A közös nyilvános fellépések, közös projektek (mint az évenkénti DesignPécs, vagy a több klaszter részvételével zajló kiállítások) a klaszter városon belüli ismertsége növelésének eszközei és a sikerérzés fontos forrásai.

\section{Frekvencia, időbeli eloszlás, gyakoriság}

A kifejezetten üzleti célú kommunikáció gyakorisága a klaszteren belül nem egyenletes időbeli eloszlású. Közös események időszakaiban sürüsödnek az üzenetváltások, eseményszegény időszakokban ritkul, gyérebbé válik a kapcsolat. Az időbeli eloszlás és tagonkénti involváltság dinamikusan változó, új projektek jelentős átrendező hatással bírhatnak. A kommunikáció stabilitása tehát gyenge. 


\section{A kommunikációt befolyásoló sajátos klaszterjellemzők}

Kivétel nélkül minden megkérdezett kiemeli a menedzsment rátermettségét, szakértelmét, aktivitását. A sikeresség titkát a klaszter vezetésében látja. Hangsúlyt kapott a klaszter elnöke, akinek habitusa a sikeresség forrása. Jelzői: "szikra típus" - kifogyhatatlan az ötletekből; "kulcsember" - határtalan a fantáziája, nem ismer korlátokat, pozitív és újszerű gondolkodású, dinamikus, nagyon aktív személyiség, erős motiváló képességgel bír, karizmatikus egyéniség, nagyon jól kommunikál, kiterjedt kapcsolati rendszerrel rendelkezik, nemzetközi perspektívában gondolkozik. A KLMről összességben is nagyon pozitív a tagok képe: nemcsak az elnöke, hanem a tagjai is, aktiváló, integratív törekvésűek.

\section{A klasztertagok véleménye a klaszteren belüli kommunikációról}

A klaszteren belüli kommunikációt a tagok a következő jelzőkkel írják le: kezdeményezö jellegü kommunikáció, ösztönzö, innovatív, nyilt, rendszeres, gyakori, ,smart”, mértéktartóan elegendő (éppen annyi, amennyire szükség van), professzionálisan szervezett. A klaszter kommunikációt befolyásoló erősségei: a klaszter elnökének személye, a dinamikus, odaadó klasztermenedzsment, a klaszter közösségösszetartó ereje, a nagy pályázati aktivitás és pályázati gyakorlat.

\section{A Pécsi Kesztyű Klaszter}

\section{A kommunikáció iránya}

A kommunikáció a klasztertagok között eseti jelleggel zajlik, amennyiben felmerül anyagbeszerzési vagy munkaerő igény. A menedzsment nem különül el élesen, inkább névleges szerepet tölt be a klaszter vezetője. A korábbiakban a közös marketinganyagok és -események kapcsán történtek együttmüködések.

\section{A kommunikáció tartalma}

A klaszter eredeti célja szerint elsősorban reklám, marketing, közös megjelenések, közös értékesítési pontok, fesztiválok és vásárok, valamint anyagbeszerzés, munkaerőhiány vagy -felesleg esetén válna intenzívvé a kommunikáció. Mára igen alacsony intenzitással és gyenge motivációval müködik a kommunikáció. A gyér kommunikáció tükre a klaszteren belüli érdektelenségnek, illetve érdekellentéteknek és a tagok közötti negatív attitüdöknek. Minthogy a bizalom hiánya csak kommunikációval orvosolható (Allport, 1999; Covey, 2011), feltehetően önerösítő folyamat zajlik (minél kevesebbet kommunikálnak a tagok, annál erősebbek a negatív attitüdök és minél erősebbek a negatív érzelmi szürők, annál jobban eltávolodnak egymástól a tagok, ez pedig tovább csökkenti a kommunikációt) (Borgulya, 2007, p. 323.). E feltevés további vizsgálatot igényelne a felmérés készítőitől.

\section{Csatornák és eszközök}

A leggyakoribb kommunikációs csatorna a telefon és a személyes megbeszélés, ugyanakkor itt is igaz, hogy a fiatalabbak már inkább az elektronikus kapcsolattartást preferálják.

\section{Gyakoriság és involváltság}

A klaszterkommunikáció heti vagy havi gyakorisággal zajlik, és jól jellemzik annak müködését a következő interjúidézetek: „egymás torkát fogják, de kesztyűs kézzel”, „,a kommunikációt sanda gyanú lengi körül”, ,attól, hogy egy klaszterben vagyunk, még nem vagyunk sülveföve együtt, verseny van”, ,a gépipari klaszterben nem rábeszélni kell a cégeket a tagságra, itt igen”, „,elsősorban akarat kérdése: nem müködik olyan fényesen a klaszter, nem találtuk meg a közös pontokat, amiben szorosabban együtt tudnánk dolgozni”.

\section{Preferált kommunikációs formák és azok eredményessége}

A klaszter missziója, hogy a márkanév épüljön, amiben jó eredményeket is értek el, a márkaboltjuk időközben gazdaságossá vált, és jól működik. Ugyanakkor a tagok több kérdésben sem tudtak egymással hatékonyan kommunikálni, közösen döntést hozni. Az interjúalanyok szerint ha megtalálnák a közös célt, akkor szükség lenne intenzívebb kommunikációra, ám közös célok nélkül csupán versenyeznek egymással. Ennek legfőbb oka, hogy érdekellentétek vannak a szük piacon, kevés a megrendelés és kevés a munkaerő. A KLT vezetői szerint mégis vannak pozitívumai a klaszternek: „összehozta a kesztyűs társadalmat”, és ,mivel nincs tagdíj, megéri tagnak lenni”. A PKK müködésének néhány éve alatt a minimálisan kialakított közös érdekek mentén a következő eredményeket érték el: közös weboldal, logó, brand és reklám, közös fesztiválszervezés, közös márkabolt és kiadványok, a klaszter kulturális örökség megőrző szerepe (Déry János gyüjtemény feltárása), „Magyar termék” titulus megszerzése. A megkérdezettek véleménye szerint ezek az eredmények klaszter nélkül nem jöhettek volna létre.

\section{A kommunikációt befolyásoló sajátos klaszterjellemzők}

Az iparágat az utóbbi évtizedben recesszió sújtotta, és az idősebb generációk háttérbe vonulásával a fiatalabbak nem tudtak megfelelö együttmüködési formákat kialakítani vagy fenntartani más kesztyüs cégekkel, így a kapcsolatok felbomlottak. A PKK 2017-ben csupán 3-4 cég valós kooperációját jelenti: az interjúalanyok megfogalmazásában a klaszter többi tagja csupán „töltelék, azért hogy meglegyen a klaszter”.

\section{A klasztertagok véleménye a klaszteren belüli kommunikációról}

Összességében a Pécsi Kesztyü Klaszter egy formálisan müködő klaszter, amelyben - annak ellenére, hogy fel tudott mutatni eredményeket a közös marketing területén - az érdekellentétek, az azonos profil és versengés miatt, valamint közös akarat és célok hiányában a tényleges gazdasági siker elmarad. 


\section{Értékelés, következtetések}

A kommunikáció támogató vagy gátló voltát a sikeresség - klasztercél, klaszterstratégia - kommunikációmenedzsment hármas összefüggésében egységes szempontok alapján elemeztük.

A Dél-Dunántúli Gépipari Klaszter mind a menedzsment, mind a tagok véleménye szerint is sikeresen müködik, a kommunikáció intenzitása, tartalma, stílusa optimális szinten támogatja a klaszter misszióját, amelyhez a menedzsment koordinációs, támogató munkája nagy mértékben hozzájárul. A klaszter kiemelkedően sikeresen müködik a képzésben, a közös beszerzésben és az egyes tagok között kapacitásbeli együttmüködésekben. A kommunikációs csatornák (telefonos, elektronikus csatornák és a benchmark találkozók) tudatosan kiépített és jól menedzselt mivolta folyamatosan segíti a közös ügyek elörevitelét, ugyanakkor figyelembe veszi az időbeni korlátokat is. Következésképpen fontos az is, hogy ne kösön le túl sok időt a kommunikáció a klaszterben, hiszen a klaszter egy szinergikus előnyöket biztosító addicionális feladat a mindennapi munkavégzés során a tagok szemszögéből. Fontos alapvetés, hogy a tagság kialakítása tudatosan történt: nem versengő, hanem egy területen, de egymást kiegészítő beszállítói-vevői kapcsolatban lévő szervezetek találhatók a klaszterben, ami kulcsfontosságú tényező a sikeresség megalapozásában.

A Kreatív Ipari Klaszter sikeresség érzetében kiemelt szerepe van a közösségépítésnek. A klaszter céljai, missziója és stratégiája, a kommunikációmenedzsment és a közösség igénye kölcsönösen pozitív, egymást erősítő kapcsolatban állnak egymással. A belső kohézió építésében, a közösségi összetartás erősítésében a közvetlen személyközi kommunikáció, a személyes találkozások a döntő fontosságúak. E tekintetben a Kreatív Ipari Klaszter rendkívül leleményes formákat vezetett be. A KLM székhelye a Co-Working House (KOHO) a KLT-k rendszeres találkozásának színhelye: iroda, tárgyaló, képzési színtér, közösségi tér. A KOHO összetartó tényezö, a klaszter otthona. A KLT-k a tartalmukban az ismereteket és a kapcsolatokat gazdagító, változatos személyes találkozásokat tartják a klaszter kötőelemének.

A rendszer erőssége, egyben azonban kritikus pontja is, hogy a karizmatikus, meghatározó személyiségre építő szervezetek sérülékenyek, a vezető személyének változása az egész szervezet gyökeres átalakulását vonja maga után. A közvetlen személyközi kommunikáció nagy súlya, bár erős összetartó kapocs, megnehezíti azt, hogy földrajzilag távolabbi helyeken működő klasztertagok hátrányok nélkül legyenek tagjai a klaszterközösségnek. A közös közvetlen üzleti (célok és) eredmények hiánya a klaszterfilozófia egy fontos pillérét téveszti szem elől.
A Pécsi Kesztyü Klaszter intern kommunikációja szervezettségében és intenzitásában elmarad a két előző klaszterétől. Az elégtelen kommunikáció nehezíti a hiányzó bizalom megteremtését. Ugyanakkor a nehézségek nem írhatók csupán a belső kommunikáció hiányosságainak számlájára, és nem oldhatók meg kommunikációs eszközökkel, de segíthetnek a szűk piacon a kitörési pontok közös megtalálásában.

\section{Korlátok}

A kutatásban, a hármas összefüggésben, leszükített modellben gondolkoztunk. Figyelmen kívül hagytunk több olyan tényezőt, amely minden vizsgált elemre különkülön is hatással van. Nem vizsgáltuk például tágabb értelemben a külső környezetet, annak változásait (a piaci, a szabályozási rendszer, a politikai tényezők hatását stb.).

Bár a vizsgált klaszterek nemzetközi kapcsolatokkal is rendelkeznek, részben nemzetközi beágyazottsággal bírnak, ezen aspektusra nem terjesztettük ki a kutatást.

Az adatfelvétel egy adott idöpillanatot tükröz, a folytonos változásokat nem vizsgálja. Nem foglalkozik azzal, hogy milyen hatással van a klasztertagok számának, vagy tevékenységi profiljuk változása a kommunikáció jellemzőire.

Kutatásunk további korlátainak tekintjük, hogy kisszámú elemen végeztük el a felmérést, három klaszterben folytattuk interjúkat. Tervezett lépésünk a kutatás nagyobb mintára kiterjesztése.

Továbbá a vizsgált három klaszter a Dél-Dunántúlon müködik, amelynek gazdasági-társadalmi helyzetét részletesebben nem elemeztük, hiszen a régióban jelenlévő klaszterek által észlelt sikerességet vizsgáltuk. A sikeresség megítélésében torzító tényező lehet a régió üzleti-gazdasági lemaradása a magyarországi prosperáló régiókhoz képest. Ezért a környezet adta lehetőségek között kell értelmezni a klaszterek üzleti és eszmei (relatív) sikerességét, lobbierejét, elért eredményeit. További kutatási irány a potenciális stakeholderekre, befolyásoló szervezetekre, intézmények hatásaira fókuszált vizsgálat: így az egyetem, az önkormányzat, a kamarák, a külföldi partnerek, a társadalmi csoportok, a helyi és országos politikai döntéshozók stb. szerepének feltárása a kommunikációban.

\section{Összegzés}

Empirikus kutatásunk során három Dél-Dunántúlon múködő klasztert mértünk fel félig strukturált interjús lekérdezés formájában: a Kreatív Ipari Klasztert, a Dél-Dunántúli Gépipari Klasztert és a Pécsi Kesztyű Klasztert. Az összehasonlítás legfontosabb jellemzőit a 4. táblázat foglalja össze. 


\begin{tabular}{|c|c|c|c|}
\hline & Dél-Dunántúli Gépipari Klaszter & Kreativ Ipari Klaszter & Pécsi Kesztyü Klaszter \\
\hline Tagok száma & $29 \mathrm{db}$ & $38 \mathrm{db}$ & $7 \mathrm{db}$ \\
\hline Misszió & $\begin{array}{c}\text { Együttmüködés } \\
\text { (beszállítói, beszerzési, erőforrás, } \\
\text { értékesítés), tapasztalatcsere }\end{array}$ & $\begin{array}{c}\text { Jövedelemtermelő képesség } \\
\text { fokozása, kreatív ágazatok } \\
\text { összekapcsolása }\end{array}$ & $\begin{array}{l}\text { Közös márkaépítés, } \\
\text { közös beszerzés }\end{array}$ \\
\hline Alapitása & $\begin{array}{l}\text { Felülröl koordinált } \\
\text { (PBKIK kamara), + alulról } \\
\text { meglévő kapcsolatokból }\end{array}$ & $\begin{array}{l}\text { Alulról kezdeményezett, } \\
\text { baráti-szakmai alapokon }\end{array}$ & $\begin{array}{l}\text { Alulról induló, } \\
\text { korábbi szakmai alapokon }\end{array}$ \\
\hline Fókusza & Üzleti & Nem üzleti & Üzleti \\
\hline Akkreditáció & Rendelkezik & Nem rendelkezik & Nem rendelkezik \\
\hline Tagszervezetek közötti viszony & Kooperatív, kiegészítő & $\begin{array}{l}\text { Kooperatív, kiegészítő, } \\
\text { kevés versengés }\end{array}$ & Versengö \\
\hline Tagdij mértéke & Magas & Alacsony & Nincs tagdíj \\
\hline $\begin{array}{c}\text { Tagok cégprofilja (méret, kor, } \\
\text { tevékenység) }\end{array}$ & Heterogén & Heterogén & Homogén \\
\hline Müködés & Sikeres & Sikeres & Nem múködő \\
\hline Eredmény & $\begin{array}{l}\text { Számos közvetett és közvetlen } \\
\text { szinergia (pénzügyi eredmény is) }\end{array}$ & $\begin{array}{c}\text { Számos kreatív ötlet, innováció, } \\
\text { emberi kapcsolat }\end{array}$ & $\begin{array}{l}\text { Néhány marketing kiadvány, } \\
\text { fesztivál, brand }\end{array}$ \\
\hline Lobbierö & $\begin{array}{l}\text { Helyi szinten erős, } \\
\text { régióban alacsony }\end{array}$ & Csekély & Csekély \\
\hline Fókusztémák & $\begin{array}{l}\text { Képzés, beszerzés, kapacitás és } \\
\text { erőforrás megosztás }\end{array}$ & $\begin{array}{l}\text { Ötletgenerálás, inspiráció, } \\
\text { baráti kapcsolatok hálója }\end{array}$ & Marketing \\
\hline Klaszter összetartó ereje & $\begin{array}{c}\text { Formalizált rendszer }+ \\
\text { menedzsment együttmük. }\end{array}$ & Klaszterelnök személyisége & $\begin{array}{l}\text { Bizalom, közös pontok és akarat } \\
\text { hiánya miatt nincs }\end{array}$ \\
\hline Szervezeti kultúra & $\begin{array}{l}\text { Baráti légkör, oldott hangulat, } \\
\text { jó közösség }\end{array}$ & $\begin{array}{l}\text { Baráti légkör, oldott hangulat, } \\
\text { jó közösség }\end{array}$ & Személyi ellentétek, konfliktusok \\
\hline Klasztertagságból fakadó elönyök & $\begin{array}{c}\text { Közös beszerzések, } \\
\text { szakmai tapasztalatcsere, } \\
\text { képzések, információcsere, } \\
\text { benchmark, eróforrás megosztás }\end{array}$ & $\begin{array}{l}\text { Közösség, gondolkodás, } \\
\text { információáramlás, pályázati } \\
\text { lehetőségek, segítségnyújtás, } \\
\text { brand, lehetőségek feltárása }\end{array}$ & $\begin{array}{l}\text { „Magyar termék” titulus, közös } \\
\text { kiadvány, márkabolt, fesztivál }\end{array}$ \\
\hline Klasztertagok véleménye & $\begin{array}{c}\text { Nagyon sok pozitív következménye } \\
\text { van a klasztertagságnak }\end{array}$ & $\begin{array}{c}\text { Nagyon sok pozitív következménye } \\
\text { van a klasztertagságnak }\end{array}$ & $\begin{array}{c}\text { Van néhány pozitív következménye } \\
\text { a klasztertagságnak }\end{array}$ \\
\hline Kommunikáció intenzitása & Heti szintü & Heti szintü & Havonta vagy ritkábban \\
\hline $\begin{array}{l}\text { Kommunikációs csatornák és } \\
\text { sajátos eszközök }\end{array}$ & $\begin{array}{l}\text { E-mail, telefon, személyes } \\
\text { megbeszélések mellett havi } \\
\text { rendszerességü klasztertag- } \\
\text { látogatások (benchmark) }\end{array}$ & $\begin{array}{c}\text { E-mail, telefon, személyes } \\
\text { megbeszélések, klaszterreggeli, } \\
\text { közösségi programok, rapid randi, } \\
\text { benchmark, KOHÓ }\end{array}$ & $\begin{array}{l}\text { E-mail, telefon, személyes } \\
\text { megbeszélés }\end{array}$ \\
\hline Kommunikáció jellemzője & $\begin{array}{l}\text { Központi információelosztás } \\
\text { e-mailben mindenkinek, majd } \\
\text { adott kérdésben érintettek szükebb } \\
\text { köre telefonon, személyesen }\end{array}$ & $\begin{array}{l}\text { Smart: felpörög, ha szükséges, } \\
\text { semmi túlburjánzás }\end{array}$ & $\begin{array}{l}\text { Nem célja az információk } \\
\text { megosztása }\end{array}$ \\
\hline
\end{tabular}

4. táblázat Az empirikus felmérés három klaszterének összehasonlító elemzése (saját szerkesztés)

A gépipari és a kreatív ipari klaszter között számos hasonlóságot lehet felfedezni mind sikerességükben, mind működésükben: mindkettő rendkívül jól működő klaszter, a tagok elégedettek a klaszterből származó elönyökkel. Különbségük abban áll, hogy a gépipari klaszter elsősorban üzleti célok megvalósítása érdekében jött létre, míg a kreatív ipari klaszter ötletgeneráló, innovatív, közösségépítő és baráti-üzleti kapcsolatokat kialakító szerepe áll a középpontban. Eltérés van a klasztertagok és a klaszter által érintett munkavállalók számában is (KIK több klasztertag, de kevesebb érintett, DDGK fordítva). A kesztyüipari klaszter az előző két klaszter tükrében nem jól múködő gyakorlatot jelenít meg, ám a vizsgálat szempontjából kifejezetten alkalmas arra, hogy azonosítani lehessen a müködtetés szempontjából fontos kulcstényezőket, siker-és rizikófaktorokat.

A kommunikáció tekintetében közös, hogy a KLM a célokkal összhangban, professzionálisan szervezi a belső kommunikációt, smart módon működik: pont az, pont annyi, ami és amennyi ésszerü és pont úgy, ahogyan szük- ség van rá. A kommunikáció egyszerre központi-elosztó jellegü (a közös információkban) és hálós is, mégha ez utóbbi intenzitása el is marad a KLM és a KLT kommunikációja mögött. A gépipari klaszter - üzleti céljaival összehangban - kommunikációjában nagyobb hangsúlyt helyez az üzleti egyeztetésekre, a KIK pedig olyan személyes találkozások széles körét nyújtja, amelyek keretében a gondolatok felszabadíthatók.

A két pozitív és egy negatív gyakorlati példa tapasztalataiból kiindulva megállapítható, hogy a kommunikáció lehetőségét megalapozó közös célok és érdekek, közös akarat, motiváció és jó emberi kapcsolatok kulcsfontosságúak a klaszterek müködésében. Bebizonyosodott, hogy a sikeresség nem nélkülözheti a professzionális kommunikációmenedzsment müködtetését: a célok és a kommunikáció összehangolását, a tagok rendszeres tájékoztatását, az intenziv és többcsatornás kapcsolattartást, a közvetlen személyközi kommunikációra épülö folyamatos tapasztalatcserét. A kutatás igazolta, hogy egyértelműen pozitív az összefüggés a klasztertagok sikerességérzete és a jól 
működő belső kommunikáció között. A kommunikációmenedzsment a tudatos kommunikációs folyamatokon keresztül - közvetett módon - egyértelmüen pozitívan befolyásolja a klaszter és a KLT-k sikerességét.

\section{Felhasznált irodalom}

Allport, G. W. (1999): Az elöítélet. Budapest: Osiris Kiadó Bentele, G. - Will, M. (2006): Public Relations als Kommunikationsmanagement. In: Schmid, B.F. - Lycek, B. (Hrsg.): Uunternehmenskommunikation. Wiesbaden: Gabler, p. 151-183.

Blassini, B. - Dang, R. J. - Minshall, T. - Mortara, L. (2013): The Role of Communicators in Innovation Clusters (Chapter 8.). In: Pfeffermann, N. - Minshall, T. Mortara, L. (2013): Strategy and Communication for Innovation. Berlin-Heidelberg: Springer Vlg., p. 119.

Borgulya Ágnes (2007): Értékrendi konfliktus - pszichikai zaj a kultúraközi kommunikációban. In: Heltai (Szerk.): Nyelvi modernizáció. Gödöllő: MANYE Szent István Egyetem, p. 321-329.

Carbonara, N. (2005): Information and communication technology and geographical clusters: opportunities and spread. Technovation, 25, p. 213-222.

Covey, S. M. R. (2011): A bizalom sebessége. Budapest: HVG Könyvkiadó

Cluster Navigators Ltd. (2001): Cluster Building: A Toolkit. A Manual for starting and developing local clusters in New Zealand. Prepared by Cluster Navigators Ltd (C) Cluster Navigators Ltd. 2001. Letöltve: http:// www.vaxtarsamningur.is/Files/Skra_0023777.pdf (2018.01.20.)

Dorsch Lexikon der Psychologie. Letöltve:

Drucker, P. (1954): Practice of Management. New York: Harper

(The) European Cluster Memorandum 2008 (2008): Letöltve: https://www.clusterportal-bw.de/downloads/ publikation/Publikationen/download/dokument/european-cluster-memorandum/ (2018.01.20.)

Eurostat Yearbook 2002 (2002): Letöltve: http://ec.europa. eu/eurostat/web/products-statistical-books/-/KS-4001-319 (2018.01.20.)

Felzensztein, C. - Deans, K. R. (2013): Marketing practices in wine clusters: Insights from Chile. Journal of Business \& Industrial Marketing, 28 (4), p. 357-367. https://doi.org/10.1108/08858621311313947

Goglio-Primard, K. - Crespin-Mazet, F. (2011): Knowledge transfer within clusters: the catalyst role of private collective support structures. Management \& Avenir, 50 (10), p. 190-206. DOI :10.3917/mav.050.0190

Gonda Tibor (2012): A turizmus térségi szerveződésének új formája. PhD-értekezés. Pécs: PTE TTK Földtudományi Doktori Iskola

Hartmann, B. (2016): Kommunikationsmanagement von Clusterorganisationen. Wiesbaden: Springer Fachmedien DOI 10.1007/978-3-658-11111-3

Heckhausen, H. - Schmalt, H. D. - Schneider, K. (1998). Achivement motivation in perspective. New York. Academic Press https://portal.hogrefe.com/dorsch/erfolg-und-misserfolg/ (2018.03.28.)
Huttenloher, T. (2006): Das Clusterkonzept im Standortmarketing der Bundesländer. Berlin: Wvb, Wissenschaftlicher Verlag

Kaminski, S. (2009): Die regional Clustermarke: Konzept strategischer Markenführung. Wiesbaden: Gabler Vlg DOI 10.1007/978-3-8349-8252-0

KIK (2018): A Kreatív Ipari Klaszterről. Letöltve: http://www.kikk.hu/hu/klaszter/a-klaszterrol.html (2018.04.01.)

Kocsis Alexandra (2012): A multinacionális vállalatok szerepe a hazai klaszterekben. Vezetéstudomány, 43. évf. Klnsz., p. 24-35.

Krugman, P. (1991): Geography and Trade. Cambridge, Massachusetts: MIT Press

Lampropoulou, C. - Tregear, A. (2011): Inter-firm relations in SME clusters and the link to marketing performance. Journal of Business \& Industrial Marketing, 26 (6), p. 421-429. https://doi.org/10.1108/08858621111156412

Lengyel Imre (2001): Iparági és regionális klaszterek - tipizálásuk, térbeliségük és fejlesztésük főbb kérdései. Vezetéstudomány, 32. évf. 10. sz. p. 19-43.

Lengyel I. - Deák Sz. (2002): 7. Klaszter: a helyi gazdaságfejlesztés egyik sikeres eszköze. In: Buzás N. - Lengyel I. (szerk.) (2002): Ipari parkok fejlődési lehetőségei: regionális gazdaságfejlesztés, innovációs folyamatok és klaszterek. Szeged: SZTE GTK, JATEPRess, p. 125-153.

Lippert Róbert - Gaál Zoltán - Kovács Tamás (2015): A vezetői szerepek és a szervezeti kultúra hatása a klasztersiker érettségi modelljére. Vezetéstudomány, 46. évf. 8. sz. p. 2-13.

Lissoni, F. (2001): Knowledge codification and the geography of innovation. Research Policy, 30, p. 1479-1500. DOI: http://citeseerx.ist.psu.edu/viewdoc/download?d oi $=10.1 .1 .477 .2563 \&$ rep $=$ repl\&type $=$ pdf

Longhi, C. (1999): Networks, collective learning and technology development in innovative high-technology regions: The case of Sophia-Antipolis. Regional Studies, 33 (4), p. 333-342. DOI: http://www.tandfonline. com/doi/abs/10.1080/713693559

Negruşa, A. - Rus, R. - Sofică, A. (2014): Innovative tools used by business networks and clusters in communication. Procedia - Social and Behavioral Sciences, 148, p. 588-595. DOI:10.1016/j.sbspro.2014.07.084.

Nemzeti Kutatási, Fejlesztési és Innovációs Hivatal (2016): Hazai klaszterek, Akkreditált klaszterek. Letöltve: http://nkfih.gov.hu/innovacio/klaszterek/hazaiklaszterek (2016.10.07.)

Østergard, C. R. (2009): Knowledge flows through social networks in a cluster: Comparing university and industry links. Structural Change and Economic Dynamics, 20, p. 196-210. DOI: 10.1016/j.strueco.2008.10.003

Pfannenberg, J. - Zerfass, A. (Hrsg.) (2005): Wertschöpfung durch Kommunikation. Frankfurt am Main: Frankfurter Allgmeine Buch

Pfannenberg, J. (2005): Kommunikation-Controlling im Value Based Management: Die monetäre Wertschöpfung von Kommunikation steuern und messen. In: 
Pfannenberg, J. - Zerfaß, A. (Hrsg.): Wertschöpfung durch Kommunikation. Frankfurt am Main: Frankfurter Allgemeine Buch, p. 132-141.

Pfeffernkorn, E. J. (2009): Kommunikationscontrolling in Verbindung mit Zielgrößen des Markenwertes. Wiesbaden: Gabler Fachverlag

Porter, M. E. (1990): The Competitive Advantage of Nations. New York: The Free Press

Rogers, E. M. - Kincaid, D. L. (1981): Communication Networks: Toward a New Paradigm for Research. New York: Free Press, https://oi. org/10.1086/227967

Rogers, E. M. (1986): Communication Technology: The New Media in Society. New York: Free Press

Rosenfeld, S. A. (2002): Creating Smart Systems. A Guide to Cluster Strategies in Less Favoured Regions. Letöltve: https://www.researchgate.net/publication/237285965_Creating_Smart_Systems_A_guide_to_cluster_strategies_in_less_favoured_regions (2016.10.07.)

Röhrig, S. (2005): Wertschöpfung durch Kommunikation im Bereich DaimlerChrysler Classic. In: Pfannenberg, J. - Zerfass, A. (Hrsg.): Wertschöpfung durch Kommunikation. Frankfurter Allgmeine Buch, Frankfurt am Main. p. 142-156.
Ternai Katalin - Borbásné Szabó Ildikó (2015): eBEST platform a KKV-klaszterek operatív és együttmüködési folyamatainak támogatására. Vezetéstudomány, 46. évf. 9-10. sz. p. 57-66.

Vas Zsófia (2009): Role of Proximity in Regional Clusters: Evidence from the Software Industry. In: Bajmócy, Z. - Lengyel, I. (eds): Regional Competitiveness, Innovation and Environment. Szeged: JATEPress, p. 162-182.

Wiener, B. (1992): Human Motivation. Methaphors, Theories and Research. Newbury Park. Sage

Zerfaß, A. - Pfannenberg, J. (2005): CommunicationsControlling: neue Herausforderungen für das Management. In: Pfannenberg, J. - Zerfaß, A. (Hrsg.): Wertschöpfung durch Kommunikation. Frankfurt am Main: Frankfurter Allgemeine Buch, p. 14-27.

Zerfa $\beta$, A. (2004): Unternehmensführung und Öffentlichkeitsarbeit. Grundlegung einer Theorie der Unternehmenskommunikátion und Public Relations. Wiesbaden: VS Verlag für Sozialwissenschafen

Zerfa $\beta$, A. (2005): Innovationsmanagement und Innovationskommunikation - Erfolgsfaktor für Unternehmen und Regionen. In: Mast, C. - Zerfa $\beta$, A. (Hrsg.): Neue Ideen erfolgreich durchsetzen. Das Handbuch der Innovationskommunikation. Frankfurt: Frankfurter Allgemeine Buch 